\title{
Wpływ umysłu na zdrowie i ciało, czyli psychosomatyka i radzenie sobie ze stresem
}

\author{
Krzysztof Kalkowski \\ Uniwersytet im. Adama Mickiewicza w Poznaniu \\ Wydziat Biologii, Laboratorium Dydaktyki i Ochrony Przyrody \\ E-mail:krzkal1@st.amu.edu.pl \\ tutor: prof. UAM dr Agnieszka Cieszyńska \\ Uniwersytet im. Adama Mickiewicza w Poznaniu \\ Wydziat Biologii, Laboratorium Dydaktyki i Ochrony Przyrody
}

Stowa kluczowe: psychosomatyka, stres, radzenie sobie, choroby psychosomatyczne

\section{Wstęp}

Człowiek to nie tylko istota złożona z układów biologicznych, ale również tych mniej namacalnych, czyli psychicznych. Oczywiście te ostatnie wynikają, czy też są efektem pracy układów biologicznych, aczkolwiek można je traktować jako byt nieco bardziej abstrakcyjny, czy też przynajmniej częściowo odrębny od ciała. Ten częściowo odrębny od somatyki byt zbudowany jest z wielu składowych, które wzajemnie na siebie oddziałują. I tak, wyróżnić można procesy afektywne, czyli nasze emocje, procesy motywacyjne, które ukierunkowują nasze działanie na cel oraz procesy poznawcze, czyli wszelkiego rodzaju struktury i mechanizmy odpowiedzialne za to w jaki sposób poznajemy świat. Wymienić tutaj można; pamięć, uwagę, percepcję, czy bardziej złożone procesy poznawcze, jak język i myślenie (Nęckai in., 2013). Zgodnie z socjoekologicznym modelem zdrowia, zarówno psychika, ciało, jak i środowisko są nieodłącznym elementem wpływającym na dobrostan człowieka. Niemniej, równie istotnym jest fakt, że powyższe czynniki na siebie oddziałują, wykazując tym samym powiązanie. (Heszen i Sęk, 2007). Związek pomiędzy tymi czynnikami można spotkać nawet w przekazach ludowych i potocznych. Na przykład, znane wszystkim powiedzenie, "W zdrowym ciele, zdrowy duch.”. Przysłowie to odwołuje się właśnie do związku, między prowadzeniem aktywnego trybu życia, a dobrostanem duchowym czy też psychicznym. Podobnie, to co myślimy i czujemy, może mieć wpływ na to, w jaki sposób reaguje nasz organizm na poziomie biologicznym. Oznacza to, że człowiek poprzez swoje działania i odczucia oraz sposób myślenia i inne procesy poznawcze, wpływa na poziom własnej kondycji zdrowotnej, zachowując się prozdrowotnie lub wręcz przeciwnie. Jednym z aspektów, istotnym dla zdrowia jednostki jest zarządzanie własną reakcją stresową. 
Psychosomatyka i stres w kontekście chorób i funkcjonowania człowieka

Z pomocą przychodzi dziedzina nauki znajdująca się na pograniczu psychologii i medycyny, zwana psychosomatyką, z greckiego, psyche, czyli dusza oraz soma, czyli ciało (Tylka, 2000). Psychosomatyka bada związek i wpływ psychiki na ciało jednostki albo ujmując rzecz nieco szerzej, spogląda całościowo na człowieka, biorąc pod uwagę zarówno w zdrowiu jak i chorobie, więcej komponentów, aniżeli sam aspekt somatyczny (Tylka, 2000). Wachlarz wpływu psychiki na organizm człowieka jest szeroki i może odnosić się zarówno, do spraw tak podstawowych i adaptacyjnych dla człowieka, jak reakcje fizjologiczne, na przeżywane przez nas emocje, na przykład pocenie się, obniżenie lub podwyższenie temperatury ciała, przyspieszony oddech oraz zaczerwienienie skóry. (Zimbardo i in.,2017). Skończywszy na wszelkiego rodzaju pogorszeniu funkcjonowania poszczególnych narządów, a nawet chorobach, wynikających z przewlekłego doświadczania stresu (Tylka, 2000). Przykładem takich chorób mogą być; zaburzenia snu, migrena, zaburzenia łaknienia, choroby skóry, przewodu pokarmowego, układu sercowonaczyniowego, a nawet nowotwory (Tylka, 2000). Co istotne, stres może wpływać na rozwój poszczególnych chorób somatycznych, tworząc podatny na daną patologie grunt, jak w przypadku zawałów, ale może również modyfikować przebieg niektórych chorób, tak jak ma to miejsce w przypadku w astmy (Spielman i in., 2020). I tak, zawał serca może mieć wiele przyczyn. Jedną z nich jest nadciśnienie tętnicze (Spielman i in., 2020). Badania pokazują, że stres zawodowy, praca pod presją czasu, jak i klęski życiowe oraz przewlekły hałas powodują wzrost ciśnienia tętniczego krwi, a w konsekwencji pogorszenie kondycji układu sercowo-naczyniowego, co istotnie zwiększa ryzyko za- wału (Spielman i in., 2020). W jednym z eksperymentów poproszono badanych o wykonywanie kilku zadań pod presją czasu, takich jak; liczenie w pamięci, wystąpienie publiczne czy rysowanie w odbiciu lustrzanym (Spielman i in., 2020). Powyższe zadania stanowiły stresor podnoszący ciśnienie tętnicze badanych w porównaniu z grupą kontrolą (Spielman i in., 2020). A więc można przypuszczać, że częste narażenie na stres w pracy, wykonywanie zadań pod presją czasu może powodować powtarzające się skoki ciśnienia, obciążając tym samym układ sercowo-naczyniowy, co w dłuższej perspektywie zwiększa ryzyko wystąpienia zawału. Z kolei astma, objawia się w postaci nawracających napadów duszności, wynikających ze zwężenia światła oskrzeli (Spielman i in., 2020). Napady może prowokować wiele czynników, takich jak; zanieczyszczenia oraz obniżona temperatura powietrza, alergeny, dym papierosowy czy niektóre czynniki psychologiczne, jak na przykład silny stres (Spielman i in., 2020). I tak, niektóre badania pokazują, że stres indukowany w warunkach laboratoryjnych oraz w życiu codziennym prowokował napady podobne do tych występujących w astmie (Spielman i in., 2020). Przeprowadzono eksperyment, w którym badani zostali poproszeni o wykonanie badania spirometrycznego o określonych porach dnia, co pozwalało zobrazować funkcjonowanie ich układu oddechowego w czasie. Badanie wykazało istotny związek między poziomem odczuwanego stresu w ciągu dnia a zwężeniem światła oskrzeli, co wskazuje na istotną rolę stresu w pogorszeniu przebiegu astmy (Spielman i in., 2020).

Istotnym pojęciem w kontekście negatywnych skutków stresu, profilaktyce chorób, jak i życiu codziennym, jest pojęcie radzenia sobie. Zjawisko to dotyczy każdego $z$ nas. Jedni radzą sobie w sytuacjach trudnych lepiej, inni gorzej. Natomiast, aby mó- 
wić o radzeniu sobie ze stresem, należy wyjaśnić i zastanowić się czym jest stres i jaką pełni funkcje w naszym życiu. A więc, stres jest reakcją fizjologiczną organizmu, która pojawia się w wyniku zadziałania bodźca stresogennego i występuje najczęściej w sytuacjach ważnych, istotnych czy krytycznych a w każdym razie takich, które wymagają mobilizacji organizmu w celu poradzenia sobie z problemem. Organizm w takim wypadku "przygotowuje się" do walki ze stresorem i mobilizuje poszczególne komponenty naszego ciała. I tak, zwiększona zostaje częstotliwość skurczów serca oraz jego pojemność minutowa, pozwalając tym samym, na zwiększony przepływ krwi, zwłaszcza do mózgu oraz kończyn dolnych, przygotowując je do atawistycznej reakcji walki lub ucieczki (Sapolsky, 2010). Większa ilość krwi w naszych nogach, oznacza więcej tlenu i glukozy, które mogą zostać spożytkowane do pracy mięśni, gdy przyjdzie nam z nich skorzystać, na przykład podczas ucieczki przed goniącym nas psem. Do tego, pojawia się przyspieszony oddech, pocimy się, wyostrzają się nasze zmysły oraz wydzielane są różnego rodzaju hormony, odpowiedzialne za reakcje stresową, na przykład steroidy, takie jak kortyzol czy kortykosteron (Sapolsky, 2010). Z drugiej strony układ nerwowy hamuje procesy zbędne w danym momencie, jak na przykład trawienie i perystaltyka jelit. Najważniejszy cel w tym momencie to przetrwać. Organizm robi wszystko co może, aby postawić nasze ciało w stan gotowości i wykorzystać oraz zgromadzić jak najwięcej, energii, to znaczy zasobów potrzebnych do poradzenia sobie ze stresorem (Sapolsky, 2010). Warto zaznaczyć, że dzieje się tak nie tylko wtedy, gdy istnieje realne zagrożenie, na przykład w postaci ataku na naszą personę, przez grupę osób o nieznanej nam proweniencji, ale również wtedy, gdy stresuje nas egzamin na studiach, denerwujemy się w poczekalni $u$ dentysty czy w przypadku występowania przed dużą publicznością.
Nasz organizm, początkowo wzmaga naszą odporność i zwiększa nasze zasoby w celu radzenia sobie, ale co się dzieje gdy taka sytuacja trwa zbyt długo lub gdy stresujemy się zbyt często? Sytuację można porównać do silnika, który nieprzerwanie musi pracować na maksymalnych obrotach. W pewnym momencie, któryś z elementów nie wytrzyma presji tempa i spowoduje awarie urządzenia. Podobnie sytuacja wygląda u człowieka, u którego przedłużający się stres wpłynie na osłabienie odporności, za którą odpowiada układ immunologiczny. Zasoby się wyczerpują a jednostka zaczyna odczuwać zmęczenie wynikające z ciągłej mobilizacji (Sapolsky, 2010). W sytuacji wiecznie trwającego i przedłużającego się stresu nie dość, że wyczerpujemy nasze zasoby energii, to jeszcze, organizm zostaje wystawiony, ze względu na obniżoną odporność, na atak przez różnego rodzaju patogeny. Ta obniżona odporność jest efektem działania takich hormonów jak kortyzol, które należą do grupy hormonów steroidowych, uwalnianych podczas przedłużającej się reakcji stresowej (Sapolsky, 2010). Jesteśmy wtedy bardziej podatni na zakażenia, nasza odporność szwankuje, a potencjalne choroby łatwiej mogą się nam przytrafić (Sapolsky, 2010). Ważne jest więc, aby zwracać uwagę na to jak reagujemy na sytuacje stresowe oraz jak wiele ich doświadczamy. Ponadto, istotne jest jak bardzo mają one wpływ na nasze życie społeczne, emocjonalne oraz zawodowe. Warto również zadać sobie pytanie, gdy już się takie sytuacje pojawią, to; czy mamy jakieś gotowe, skuteczne a zarazem elastyczne strategie, pozwalające nam poradzić sobie z takimi wydarzeniami? Gdyż trzeba wiedzieć, że tyle ile stresorów, tyle sposobów radzenia sobie i niekoniecznie każdy sposób musi być adekwatny do aktualnie doświadczanego stresora. 
Jak radzić sobie ze stresem?

Stresuje się każdy z nas, różnimy się tylko sposobem radzenia sobie. A zatem pytania które wypadałoby postawić brzmią następująco, co można zrobić aby radzić sobie ze stresem lepiej lub skuteczniej? A także, jak zapobiegać rozwojowi wyżej opisanych chorób psychosomatycznych, wynikających z doświadczania przewlekłego stresu? Oczywiście radzenie sobie ze stresem to tylko jeden z elementów czy obszarów, w jakim możemy wpływać na nasze ciało poprzez psychikę. I tak, w celu radzenia sobie ze stresem odwołać można się zarówno do farmakoterapii, jak i psychoterapii. Farmakoterapia, może zostać wykorzystana w najróżniejszy sposób, począwszy od leków uspokajających, nasennych, aż do leków rozluźniających, które osobie żyjącej w wiecznym napięciu mają przynieść przynajmniej chwilową ulgę. Przykładem może być stosowany przez niektórych muzyków czy aktorów, lek z grupy beta-blokerów, propranolol. Beta-blokery to specyficzna grupa leków hamująca działanie układu współczulnego (Korbut, 2019). Aczkolwiek można zapytać, jaki związek ma muzyka ze stresem? Otóż, za większość wyżej opisanych reakcji mających zmobilizować organizm w czasie stresu odpowiada układ współczulny. To on zwiększa częstotliwość rytmu serca, rozszerza oskrzela i zwiększa dopływ krwi do poszczególnych narządów. Idąc za przykładem muzyków czy aktorów, którym zdarza się stosować takie leki, powodują oni tym samym hamowanie ich układu współczulnego a co za tym idzie, fizjologii reakcji stresowej. (Sapolsky, 2010). Ciekawym przykładem mogą być muzycy grający na instrumentach dętych potrzebujący nieco śliny, aby odpowiednio nawilżyć ustnik co pozwala im dobrze zagrać na swoich instru- mentach. Co istotne, w czasie reakcji stresowej, tak samo jak hamowane jest trawienie oraz perystaltyka jelit, podobnie zostaje zahamowane wydzielanie śliny, co w konsekwencji może utrudniać grę na instrumencie. Zastosowanie beta-blokerów niweluje ten efekt, dodatkowo zmniejszając napięcie związane ze stresem, który może towarzyszyć występom (Sapolsky, 2010). Warto jednak wspomnieć, że jak każdy lek, również beta-blokery mogą mieć negatywne skutki uboczne. Ponadto, farmakologiczne wspomaganie się usuwa przed nami przeszkodę w postaci stresu czy napięcia, ale nie rozwiązuje problemu, który przypuszczalnie leży u jego podłoża. Po trzecie, nie każdy może z takiego leku skorzystać, ze względu na współistniejące choroby lub objawy, takie jak astma czy bradykardia, gdzie stosowanie propranololu może być dodatkowym zagrożeniem dla zdrowia lub nawet życia i nie jest rekomendowane (Korbut, 2019). Do tego, należy sobie uświadomić, że lek w końcu przestanie działać, a my będziemy tacy jak wcześniej. Można zatem zadać pytanie, co będzie dalej? Co będzie w przypadku kolejnego publicznego występu? Czy przyjmowanie leków uspokajających nie jest obarczone ryzykiem potencjalnego uzależnienia, a także powierzchownego traktowania problemów, będących przyczyną napięcia nerwowego? Konkludując, leki nie rozwiązują naszych problemów psychicznych, ewentualnie mogą złagodzić ich skutki i stosując je należy zawsze robić to z rozwagą oraz pod opieką lekarza. Jeśli chodzi o aspekt psychologiczny, wyróżnia się różnego rodzaju terapie, na przykład skupiające się na psychoedukacji, to znaczy poznaniu mechanizmów stresu i nauce sposobów adaptacyjnego radzenia sobie, zmianie myślenia oraz stosowaniu treningów relaksacyjnych. (Zimbardo i in., 2017). Aczkolwiek powstaje pytanie, czy możemy 
zrobić coś sami? Bez pomocy lekarza bądź psychologa? Wybitny badacz psychofizjologii stresu Robert M. Sapolsky (2010) na podstawie wieloletnich badań, opisał w swojej książce "Dlaczego zebry nie mają wrzodów" kilka ważnych czynników, mających znaczenie w adaptacyjnym radzeniu sobie. I tak, wyróżnić można, ćwiczenia fizyczne, medytacje, kontrolę poznawczą i przewidywalność, wsparcie społeczne oraz religie i duchowość, a także elastyczność poznawczą.

Ćwiczenia fizyczne, rozluźniają mięśnie, poprzez obniżenie ich napięcia, do tego poprawiają nastrój, poprzez uwalnianie betaendorfin (Sapolsky, 2010). Trzeba zdać sobie sprawę, że stres przygotowuje nasz organizm do reakcji walki i ucieczki. I nie ważne czy faktycznie musimy uciekać przed niedźwiedziem, czy mamy do wygłoszenia referat przed publicznością. Reakcja będzie podobna i spowoduje napięcie wcześniej wspomnianych mięśni, dlatego ćwiczenia fizyczne mogą pełnić tak istotną rolę $\mathrm{w}$ zwalczaniu skutków stresu. Trzeba natomiast pamiętać, że ćwiczenia fizyczne, są tak długo skuteczne jak długo ćwiczymy. Ich efekty utrzymują się do kilku godzin, maksymalnie jednego dnia, od treningu (Sapolsky, 2010). Bardziej korzystne są ćwiczenia aerobowe, czyli tlenowe, wykonywane regularnie, przynajmniej $30 \mathrm{mi-}$ nut kilka razy w tygodniu (Sapolsky, 2010). Ponadto, aktywność fizyczna ma wpływ na wydzielanie szeregu związków chemicznych odgrywających istotną rolę w modulacji samopoczucia, przeżywaniu stresu oraz nastroju (Domosławska-Żylińska i Perzak, 2013). Jednym z tych związków jest BDNF, znany jako neurotroficzny czynnik pochodzenia mózgowego (Domosławska-Żylińska i Perzak, 2013). Zwiększona ekspresja tego białka, wynikająca z podejmowania aktywności fizycznej, powoduje wzrost plastyczności oraz przeżywalności neuronów, na przykład hipokampa (Domosławska-Żylińska i Perzak, 2013). Potwierdzają to pośrednio badania dotyczące wpływu przewlekłego stresu na hipokamp, gdzie obserwuje się obniżony poziom BDNF oraz atrofię neuronów w tym obszarze, co może skutkować pogorszeniem funkcjonowania pamięci i procesu uczenia się (Domosławska-Żylińska i Perzak, 2013). Podobne wnioski, dotyczące korzyści płynących z podejmowania aktywności fizycznej w kontekście stresu, nasuwają badania dotyczące funkcjonariuszy straży pożarnej (Slendak i Cewińska, 2015). Zaobserwowano pozytywny wpływ sportu na poprawę relacji międzygrupowych, zwiększone poczucie szczęścia oraz zmniejszony poziom napięcia psychicznego, a co za tym idzie, większe poczucie rozluźnienia (Slendak i Cewińska, 2015). Ponadto, uprawianie sportu spowodowało zwiększenie pewności siebie strażaków, zmniejszone występowanie reakcji stresowych podczas akcji, a w konsekwencji lepsze przygotowanie do pełnienia służby (Slendak i Cewińska, 2015).

Z kolei medytacja obniża poziom napięcia układu współczulnego, a co za tym idzie poziom glikokortykosteroidów. Oznacza to, że układ współczulny, który pobudza nasz organizm do reakcji walki lub ucieczki oraz stymuluje go do zwiększonego wysiłku, dzięki medytacji nie będzie tak rozchwiany i pobudzony. (Sapolsky, 2010) Glikokortykosteroidy pełnią różne funkcje, między innymi regulują metabolizm węglowodanów, które są źródłem energii dla organizmu, mobilizując go tym samym do działania na najwyższych obrotach w trakcie reakcji stresowej. Ponadto hamują odpowiedź immunologiczną organizmu (Korbut, 2019). Regularne medytowanie pozwala zredukować nasilone 
oddziaływanie tych dwóch czynników na organizm (Sapolsky, 2010). Taki stan rzeczy wydają się potwierdzać badania przeprowadzone na studentach uczelni medycznej w Tajlandii (Turakitwanakan i Mekseepralard, 2013). Wyniki eksperymentu wykazały, że u studentów biorących udział w kursie dotyczącym medytacji, poziom hormonu stresu, jakim jest kortyzol, spadł o blisko $20 \%$, w porównaniu z pomiarem dokonanym przed rozpoczęciem kursu (Turakitwanakan i Mekseepralard, 2013). Do podobnych wniosków można dojść, przyglądając się badaniu przeprowadzonemu w Indiach, gdzie wykazano istotny statycznie związek, pomiędzy medytacją a redukcją poziomu kortyzolu (MacLean i Walton, 1997). Osoby badane, które regularnie stosowały technikę medytacji, przez okres czterech miesięcy, miały o 20\% niższy poziom kortyzolu w porównaniu z grupą kontrolną, u której poziom tego hormonu nie uległ zmniejszeniu (MacLean i Walton, 1997).

Zdobywanie kontroli poznawczej oraz poczucia przewidywalności jest kolejnym z aspektów, który może pomóc w redukcji negatywnych skutków stresu (Sapolsky, 2010). Czynniki te wpływają na poczucie bezpieczeństwa i stabilności. Jeśli wiemy mniej więcej, co nas czeka i mamy na to wpływ, możemy się do tego przynajmniej po części przygotować. Dzięki temu możemy przetrwać sytuacje stresową w sposób bardziej adaptacyjny lub ograniczyć jej występowanie. Oczywiście nie wszystko jesteśmy w stanie przewidzieć i nie nad wszystkim możemy mieć kontrolę, co implikuje ostrożność w stosowaniu takiej strategii.

Wsparcie społeczne, o którym pisze Sapolsky (2010) odnosi się do więzi społecznych z osobami, które znamy i lubimy. Aspekt ten dobrze ilustruje eksperyment przeprowadzony na małpach, gdzie badano poziomu glikokortykosteroidów, u osobników w różnych sytuacjach społecznych. W momencie, gdy młode małpy zostały oddzielone od matki, poziom glikokortykosteroidów wzrastał, a co za tym idzie, małpy przeżywały silny stres. Umieszczenie ich następnie w grupie małp, które znały wcześniej i na swój sposób były z nimi w przyjaznych kontaktach, powodowało zmniejszenie poziomu glikokortykosteroidów, a więc, pozwoliło zredukować poziom stresu (Sapolsky, 2010). Co istotne, efekt ten nie miał miejsca w przypadku umieszczenia małp w obcym stadzie (Sapolsky, 2010). Ponadto, badania przeprowadzone na ludziach wykazały, że wsparcie społeczne wykazuje ujemną korelację w stosunku do stężenia kortyzolu i cholesterolu w surowicy krwi (Arden, 2017). Wpływa również pozytywnie na redukcję lęku oraz wydolność układu immunologicznego, redukując tym samym podatność na przeziębienia (Arden, 2017).

Religia i duchowość, zawierzanie sile wyższej swoich problemów, postrzeganie życiowych trudności czy tragedii, jako boskiego planu, może dawać jednostce poczucie stabilności, przewidywalności, opieki, a także sporą dawkę wsparcia, w radzeniu sobie ze stresem (Sapolsky, 2010). Niemniej, należy rozróżnić pojęcia religijności i duchowości, gdzie ta druga jest mniej zinstytucjonalizowana i bardziej odnosi się do emocjonalnych przeżyć oraz jest pojęciem szerszym i bardziej ogólnym, nastawionym do wewnątrz jednostki. Czynnik ten budzi sporo kontrowersji, niemniej badania wskazują na korelację między religijnością, duchowością a długością życia i lepszym radzeniem sobie ze stresem (Sapolsky, 2010). Ciekawym przykładem, obrazującym związek pomiędzy sferą duchową a radzeniem sobie ze stresem, są 
badania przeprowadzone na ratownikach medycznych przez Ogińską-Bulik i Juczyńskiego (2016). Wykazali oni, iż stosowanie różnych strategii w obrębie ruminacji intruzywnych i refleksyjnych, prowadzi do odmiennego sposobu radzenia sobie ze stresującymi wydarzeniami i traumą w pracy ratownika. I tak, stosowanie ruminacji refleksyjnych, może prowadzić do tak zwanego wzrostu potraumatycznego, którego emanacją jest osiągnięcie pozytywnej zmiany, po traumatycznym wydarzeniu (Ogińska-Bulik i Juczyński, 2016). Przeprowadzone badanie wykazało istotną statystycznie korelację między wykorzystaniem konstruktywnych, prowadzących do skutecznego radzenia sobie, ruminacji refleksyjnych a pozytywnymi zmianami, wynikającymi z odwołania się do duchowości (Ogińska-Bulik i Juczyński, 2016). Oznacza to, iż część ratowników doświadczających przewlekłego stresu lub traumy w pracy, poradziło sobie z sytuacją trudną, zwracając się po pomoc do siły wyższej, religii czy rozwijając swoją duchowość (Ogińska-Bulik i Juczyński, 2016).

\section{Podsumowanie}

Wszystkie powyższe czynniki oraz sposoby radzenia sobie, chociaż mogą mieć swoje zastosowanie w życiu codziennym, to należy mieć na uwadzę które $z$ nich i komu polecamy. Nie każda strategia będzie odpowiednia w określonej sytuacji, czy też w przypadku konkretnej osoby. Na przykład, strategia jaką jest unikanie czynnika stresującego, może okazać się skuteczna w przypadku arachnofobii, czyli fobii dotyczącej pająków. Natomiast, w innej sytuacji strategia ta może okazać się zbędna czy wręcz szkodliwa. Zasadność stosowania takiego podejścia wynika z faktu, że w dzisiejszych czasach, w naszym rejonie geograficznym, nie spotkamy zbyt wielu groźnych pająków. Można więc można dojść do wniosku, że zwyczajne unikanie bodźca lękotwórczego może okazać się wystarczające do zredukowania poczucia lęku i stresu z tym związanego. Co innego gdy tej samej strategii użyje student w momencie egzaminu. Rozważmy następujący przypadek, w którym student zalicza egzamin, lecz nie za bardzo się na ten egzamin przygotował. Stresuje się brakiem wiedzy i tym, że może go nie zdać. Możliwe, że jednorazowe uniknięcie egzaminu i zaliczenie go w innym terminie, okaże się zbawienne, aczkolwiek, gdy zacznie unikać kolejnych zaliczeń, to w pewnym momencie, liczba egzaminów oraz ilość materiału, mogą zacząć przerastać jego możliwości a w konsekwencji nie zaliczy niczego. O wiele skuteczniejsze w radzeniu sobie ze stresem egzaminacyjnym, może być podejście zadaniowe, skupiające się na nauce i przygotowaniu do egzaminu. Konkludując, strategia ta sama, lecz kontekst inny, co skłania do wyboru odmiennego rozwiązania. Historia ta, pokazuje jakie znaczenie ma odpowiedni dobór strategii do sytuacji i osoby. Warto więc mieć to na uwadze, stosując wyżej wymienione strategie. Stres jest jeden, czynników stresujących nieskończenie wiele, podobnie jak i strategii radzenia sobie z nim, a kluczem do sukcesu jest odpowiednie dobranie sposobu do konkretnego człowieka, w konkretnej sytuacji.

\section{Literatura:}

Arden J., 2017. Neuronauka w psychoterapeutycznym procesie zmiany, Wydawnictwo Uniwersytetu Jagiellońskiego.

Domosławska-Żylińska K., Pyrzak B., 2013. Neuroendokrynne i psychospołeczne mechanizmy oddziaływania wysiłku fizycznego na psychikę, Endokrynologia Pediatryczna, 12, 3(44). 
Heszen I., Sęk H., 2012. Psychologia zdrowia, Wydawnictwo Naukowe PWN.

Korbut R., 2019. Farmakologia. Wydawnictwo PZWL.

MacLean, C., Walton K., Wenneberg S, Levitsky D., Mandarino J., Waziri R., Schneider, R. 1997. Effects of the transcendental meditation program on adaptive mechanisms: Changes in hormone levels and responses to stress after 4 months of practice. Psychoneuroendocrinology", 22(4).

Nęcka E., Orzechowski J., Szymura B., 2019. Psychologia poznawcza. Wydawnictwo Naukowe PWN

Ogińska Bulik N., Juczyński Z., 2016. Ruminacje jako wyznaczniki negatywnych i pozytywnych konsekwencji doświadczonych zdarzeń traumatycznych u ratowników medycznych. Medycyna Pracy, 67(2).

Sapolsky R., 2010. Dlaczego zebry nie maja wrzodów. Wydawnictwo Naukowe PWN.

Slendak J., Cewińska J., 2015. Rola aktywności sportowej w przeciwdziałaniu stresowi w służbie funkcjonariuszy Państwowej Straży Pożarnej. Zarządzanie Zasobami Ludzkimi (Human Resource Management), 5(106).
Spielman R., Jenkins W., Lovett M., Czarnota-Bojarska J., 2020. Psychologia. OpenStax Polska.

Turakitwanakan W., „Mekseepralard C., Busarakumtragul P., 2013. Effects of mindfulness meditation on serum cortisol of medical students. J Med Assoc Thai; 96 (suppl 1): 90-5.

Tylka J., 2000. Psychosomatyka. Wydawnictwo Uniwersytetu Kardynała Stefana Wyszyńskiego.

Zimbardo P., Johnson R.L., McCann V., 2017. Psychologia. Kluczowe koncepcje. Tom 5, Warszawa, 2017, PWN.

Notka o autorze: Absolwent psychologii o specjalności psychologia kliniczna na Uniwersytecie SWPS w Poznaniu. Obecnie student III roku Biologii i Zdrowia Człowieka na wydziale Biologii UAM w Poznaniu oraz student $V$ roku Neurobiologii na UAM, UP, AWF i UMP w Poznaniu. Interesuje się neurologia, psychopatologia, fizjologia oraz psychiatria. 